\title{
Major Salivary Gland Acinic Cell
}

\section{Carcinoma}

National Cancer Institute

\section{Source}

National Cancer Institute. Major Salivary Gland Acinic Cell Carcinoma. NCI Thesaurus.

Code C5901.

An adenocarcinoma with serous acinar cell differentiation that arises from the major salivary glands. The vast majority of cases occur in the parotid gland. Patients usually present with a slow growing mass in the parotid area. 